\title{
EMPOWERMENT OF HOMESTAY CONCEPTS IN WANGUN VILLAGE, PASIRMULYA, BANDUNG
}

\author{
Aditya Pratomo ${ }^{1 *}$, Iwan Khrisnanto ${ }^{1}$, Ferane Aristrivani Sofian ${ }^{3}$ \\ ${ }^{1}$ Hotel Management Department, Faculty of Economic and Communication, Bina Nusantara \\ University, Jakarta, Indonesia \\ ${ }^{2}$ Communication Department, Faculty of Economic and Communication Bina Nusantara University, \\ Jakarta, Indonesia \\ *pratomo_aditya@binus.ac.id
}

\begin{abstract}
This study aims to observe the condition of the Wangun tourist village of Pasirmulya Banjaran Village, Bandung, especially the houses of the residents so it meets the standards of a homestay type based on hospitality concept to empower the village developing their tourism advantage. A programmed training session is important to the resident to upgrade their knowledge of hospitality skills. The method used in this study is qualitative method with direct interviews to residents of the Wangun village. Researcher also do some direct observation to the village, and collect literatures to support this study. The result indicates that many houses are not suitable enough to run as a homestay standard to accommodate the visitor. Plus, the residents' ability to communicate and their hospitality skills are still low. After training the results obtained that several houses have been gradually able to meet the standard of a homestay based on the hospitality standard, as well as the villagers' ability to communicate and their hospitality skills are improved.
\end{abstract}

Keywords: Homestay, hospitality, tourism village

\section{INTRODUCTION}

\section{Tourism Village Concept}

Tourism village is an area that deals with the region or various customs and cultures as a potency managed as a tourist attraction by its capabilities aimed at the social and economic interests of the community. Tourism Village as an area in the form of rural environment that has a tourist attraction based on local wisdom such as customs, culture and natural wealth that has a uniqueness and authenticity in the form of a typical rural atmosphere (Hermawan, 2016). Meanwhile, according to (Nugroho, 2018) the tourism village is interpreted as a form of integration between tourist attractions, accommodation and supporting facilities presented in a structure of community life that integrates with the standard procedures and traditions.

It can be concluded again that the tourist village is one of the tourist destinations which equipped with a rural atmosphere with the attraction of common local wisdom that can only be found in the village in the form of natural beauty, customs, culture and community life supported by local tourism facilities and infrastructure by community.

In some areas, the residents of the village, somehow, have lack of ability to understand the important of hospitality standard to develop their village into a tourism destination. The Wangun Village is one of them. With the resources of the beautiful scenery, fresh and clean air plus a very hospitable residents', this place needed some support and help to develop the village. Training and development are some of the planned efforts, that can held to achieve mastery of skills, knowledge, and attitude employee or member of the organization (Kambey \& Suharnomo, 2013). Empowerment could be reach if the ability of the residents increased. Empowerment is giving of responsibility and authority over villagers to make decisions regarding the product development and decision making. Empowerment also means mutual sharing information and knowledge among villagers used to understand and 
supporting the village performance, awarding the village performance and granting of autonomy in decision making that affects the village (Chasanah, 2008).

\section{Homestay Concept}

The homestay program is defined as the experience where tourists stay with selected families, interact and gain experience of daily life at the tourists' stay and learn the culture of the surrounding cultural community (Jabil Mapjabil, 2011). Homestay is one of the facilities provided for tourists as a place to stay as long as tourists do ecotourism activities. The quality of a good homestay environment can provide satisfaction for tourists and can be used as a vehicle for education, as well as improving the quality of the surrounding environment (Eka Oktavianti, 2013).

From the references above, it can be concluded that the concept of "Living Together" or the Homestay Program is one form of alternative accommodation for tourists, where tourists will live together with the family of the homeowner and have the opportunity to enjoy the family's daily life and culture, so that the tourists have experience and can interact continuously by staying in the house of one of the residents and learning and participating in the activities of the residents of the area.

\section{Hospitality}

The Hospitality concept is an attitude of hospitality in the sense of referring to the activities of hospitality activities, namely the acceptance of tourists and services for tourists with freedom and comfort (Pristiwasa, 2017). Hospitality means hospitality, politeness, intimacy, mutual respect. Without hospitality in tourism, all products offered in tourism are like inanimate objects that have no value for sale (Pertiwi, 2013).

From the above references, it can be concluded that hospitality is a competitiveness and added value of tourism products in a region, in order to increase economic growth, encourage improvement in the quality and quantity of resources, and optimize the management of tourism potential resources in a tourist area.

\section{LITERATURE REVIEW}

Discussion about this topic have been reported by Gao and $\mathrm{Wu}$ (2017). Gao and Wu research was about how to revitalizing traditional villages through rural tourism, a case study of Yuanjia Village, Shaanxi Province, China. They found that village leader-led or elite-led development realizes endegenous and bottom-up development rather than a top-down arrangement. Farmer cooperative is a relative fair way in rural tourism benefit distribution and community participation in China. Also, embeddedness, non-embeddedness, endogeneity, empowerment and trust are main factors in Yuanjia village revitalization. (Gao \& Wu, 2017).

Balan \& Burghelea (2015) discussion in the same topic about rural tourism and its implication in the development of the Fundata Village. The development of tourism and his transformation into a huge phenomenon with far-reaching implications of economic, social, cultural, etc. has resulted in the establishment and consolidation of tourist market rural tourism is one of the forms of tourism that incorporates aspects of sustainable development, environmental protection, development of entrepreneurship, both in direct activities and those related to the practice of this form of tourism traditions and customs, ancient and unspoiled, rural life, computer games, and architecture, gives a specific identity of Fundata, the highest village in Romania (Balan \& Burghelea, 2015).

Some other concideration about this topic also comes from Sesotyaningtyas \& Manaf (2015). They analyze the sustainable tourism village development at Kutoharjo Village, Kendal Regency of Central Java. Kutoharjo has the potential to be developed as a tourism village since it has attractive objects of religious sites, natural scenery, and unique culinary. These tourism potentials are utilized by the communities in the region to encourage economic activities, so that they can generate income and upgrade their inadequate dwelling condition. This research aims to evaluate the feasibility of tourism village development in Kutoharjo using positivist research approach. The elements of tourism anatomy, social and economic feasibility, and financial feasibility are evaluated. The results based on the analysis of tourism anatomy shows that Kutoharjo has sufficient infrastructure and tourism facilities. 
Unfortunately, the financial feasibility shows that tourism village development in Kutoharjo for slum upgrading effort was not feasible. Various strategies need to be applied for tourism village development in Kutoharjo by involving people as the main subject to sustainable development (Sesotyaningtyas \& Manaf, 2015).

\section{METHODS}

This research is conducted from January until September, 2018. of the tourism development. This research aim to observe the empowerment of the The study employed descriptive qualitative method using a predominantly phenomenological paradigm (Bungin, 2010). Data were collected using two techniques, which are: (a) primary data collection through field observations and interviewing the local community, (b) secondary data collection through literature studies and institutional survey. Descriptive qualitative method was applied for analyzing the potential of the region as a tourism village based on tourism anatomy.

\section{RESULTS AND DISCUSSIONS}

\section{Description of Wangun Village, Pasir Mulya, Bandung}

Pasirmulya village is administratively included in Banjaran District, Bandung Regency, West Java Province. Rural areas still characterize the regional characteristics that are directly adjacent to the Puntang Mountain Tourism Area. Agricultural activities that develop are wetland agriculture with second crops (Sutrisno B. , 2018).

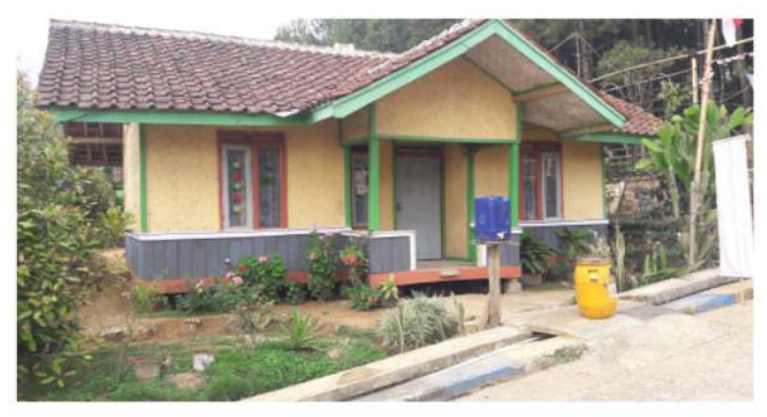

Figure 1. House of Wangun Village

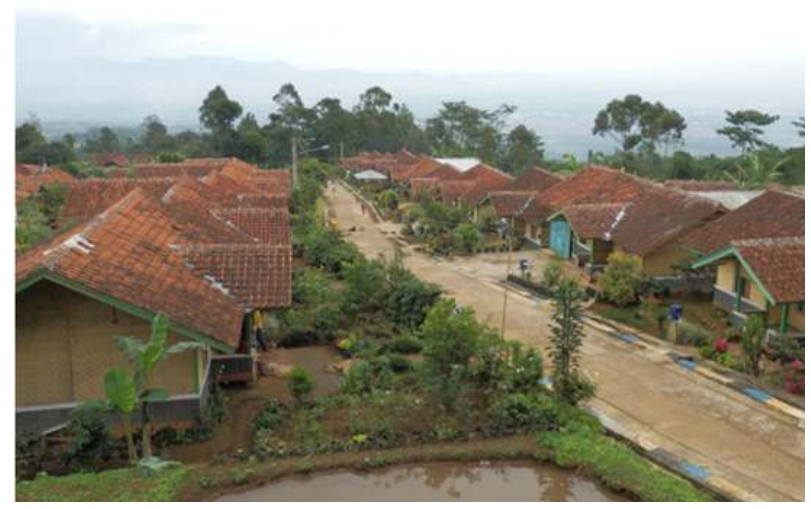

Figure 2. Wangun Village 
One infrastructure problem of Wangun is housing that is still less worthy for tourists to live with minimal sanitation. Tourism village business is the provision of accommodation in the form of residential buildings that are inhabited by their owners and partially used for rent by providing opportunities for tourists to interact in the daily lives of their owners. The tourism village business standard is a formulation of tourism business qualifications and classification which includes aspects of products, services and management. (KEMENPAREKRAF, 2014). Based on that statement, there are some shortcomings in the housing facilities of most of the houses of the Pasirmulya Village:

\section{Bedroom}

a. There are no room keys in each bedroom (because each bedroom is only equipped with curtains)

b. Not all rooms are equipped with a wardrobe and vanity.

c. Not all rooms are equipped with trash bins.

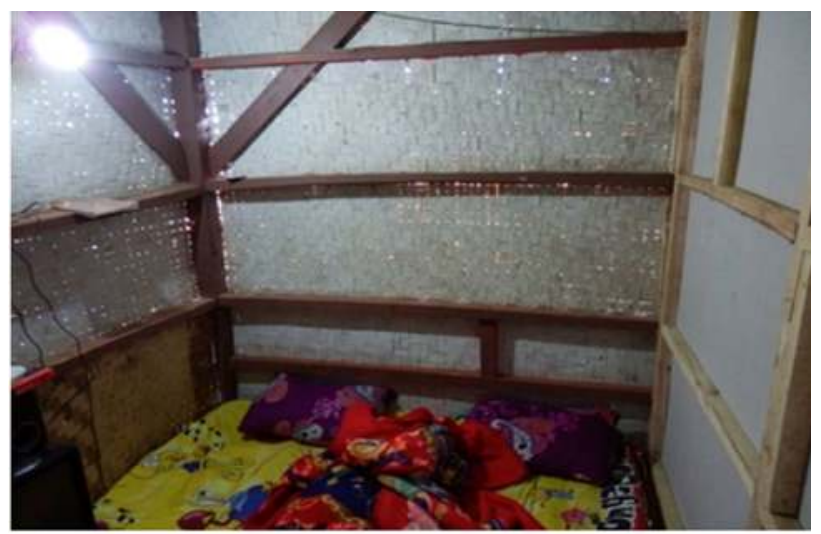

Figure 3. Bedroom Condition

2. Bathroom

a. There is no signboard with writing that is legible and installed in a place that is clearly visible.

b. Not all bathrooms are equipped with towel hangers.

c. There is no trash can in the bathroom.

d. A dirty and unhealthy toilet.

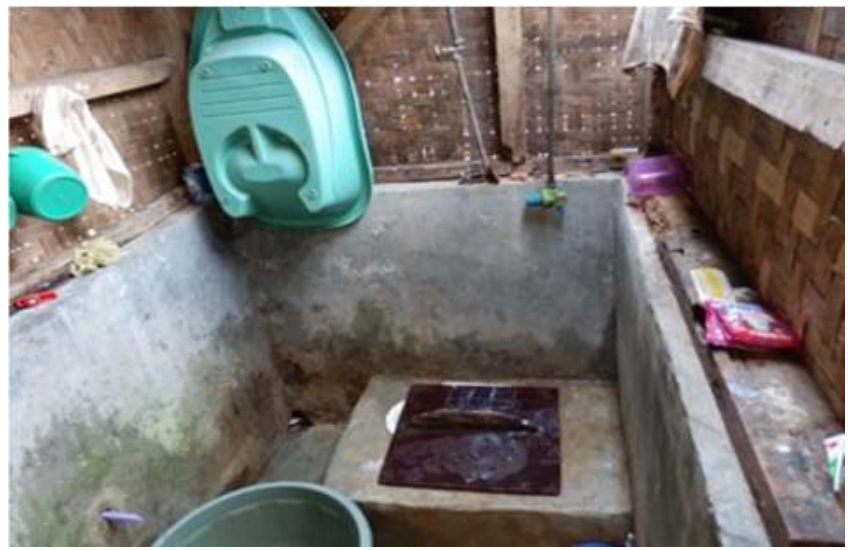

Figure 4. Bathroom Condition

\section{Kitchen}

a. The condition of the kitchen is not clean and well maintained.

b. Existing kitchen equipment is not well maintained.

c. Not equipped with a clean and well-maintained sink. 
d. Not equipped with a sewage channel that works properly.

e. Not equipped with closed waste.

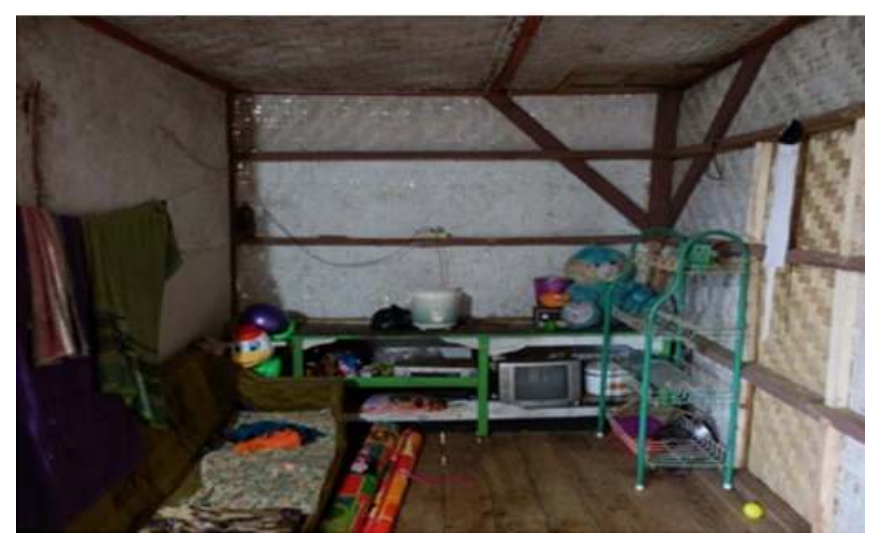

Figure 5. Kitchen

\section{Realization of Hospitality Counseling}

First implementation was conducted on April 25, 2018. Its activities consist of counselling about empowerment of homestay and language in the context of tourism village. Participants are women of village residents. The activity went well, although there were few obstacles to the delivery of information due to time and technical problems.

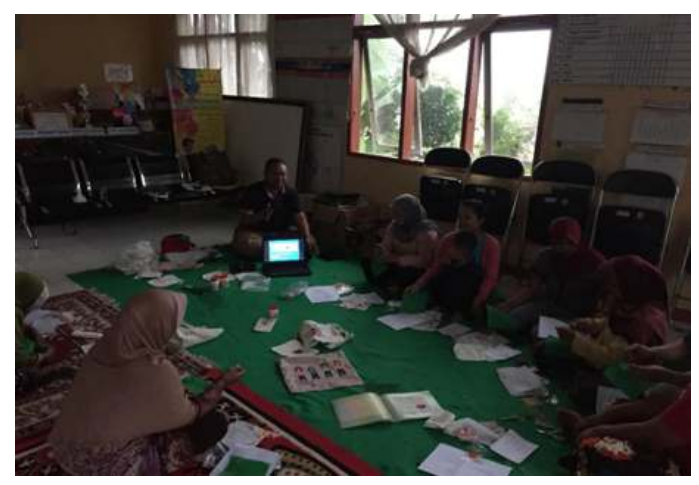

Figure 6. Counselling about Homestay

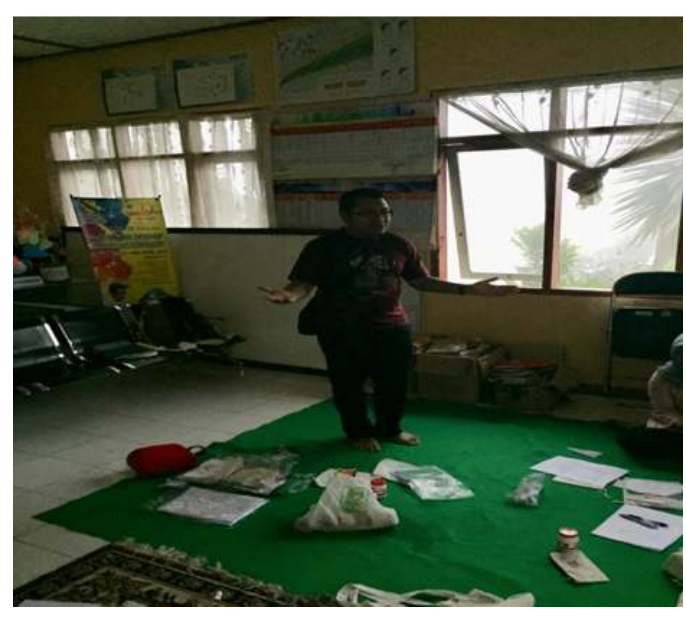

Figure 7. Counselling about Language 
The second implementation was held on August 22, 2018. The activity was counselling basic communication skills in the context of a tourist village. In this activity, there were no obstacles because counselling was carried out independently so that it was more focused. Participants consist of women both adults and teenagers. The participants were very enthusiastic and active in participating in counselling.

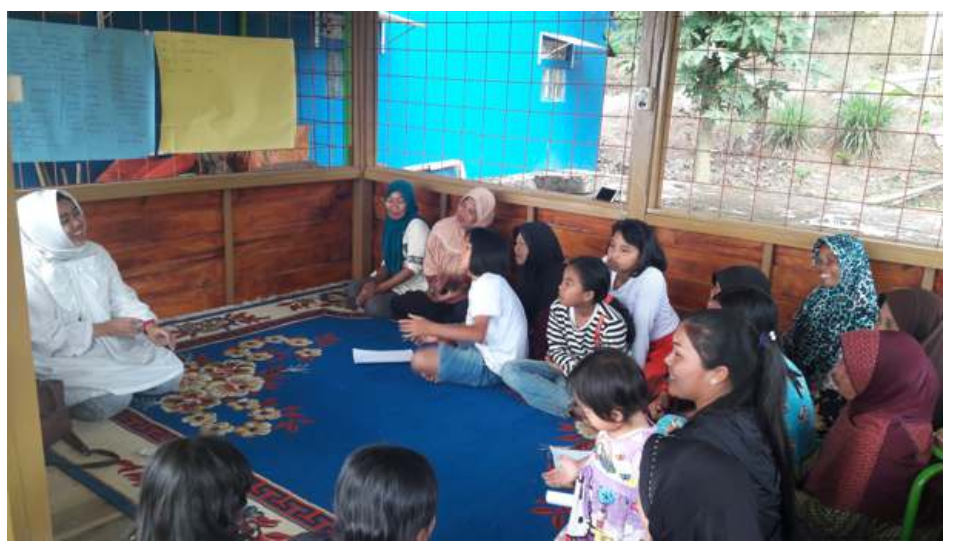

Figure 8. Basic Communication Counseling for Tourism Village Context

\section{CONCLUSION}

When monitoring on August 22, 2018, it can be concluded that some of the citizens have had the awareness to manage their dwellings well so they are suitable for habitation. Some villagers have repaired the facilities in their homes as a result of providing counselling, including some toilets that have been renovated in order to meet the requirements as a Homestay in accordance with the Homestay business Standards determined by the Ministry of Tourism and Creative Economy of the Republic of Indonesia.

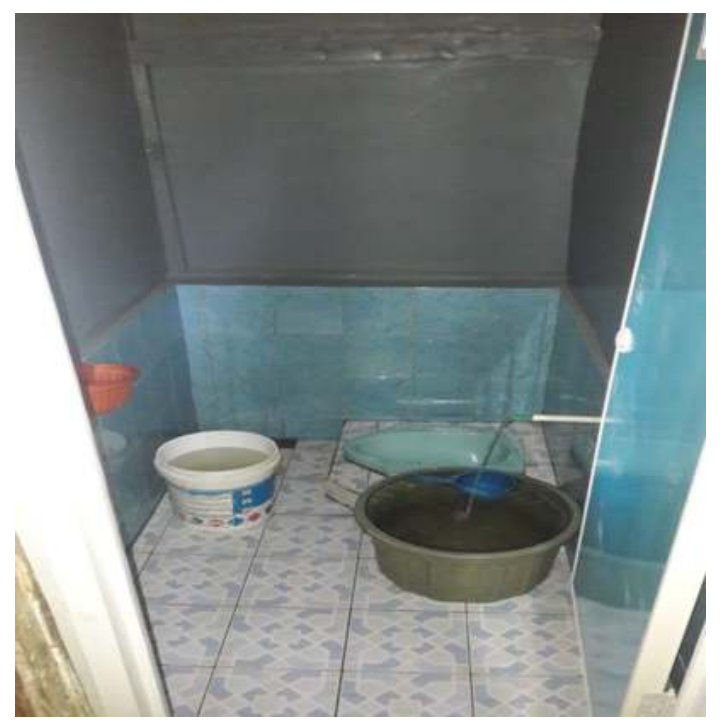

Figure 9. Bathroom condition after counselling

Likewise, the ability to speak Indonesian and English and the hospitality capabilities that can be achieved by some adults and adolescents, although only a few have been able to, the 
language and hospitality skills training efforts have achieved their goals. They need continuous training.

\section{REFERENCES}

Balan, M., \& Burghelea, C. (2015). Rural Tourism and its Implication in the Development of the Fundata Village. Procedia-Social and Behavioral Sciences , 188, 276-281.

Bungin, M. B. (2010). Penelitian Kualitatif. Jakarta: Kencana Prenada Media Group.

Eka Oktavianti, L. H. (2013). Etnobotani Pekarangan Rumah Inap (Homestay) di Desa Wisata

Gao, J., \& Wu, B. (2017). Revitalizing traditional villages through rural tourism: A case study of Yuanjia Village, Shaanxi Province, China. Tourism Management , 63, 223-233.

Hermawan, H. (2016). Dampak Pengembangan Desa Wisata Nglanggeran Terhadap Ekonomi Masyarakat Lokal . Jurnal Pariwisata, Vol.III No.2.

Jabil Mapjabil, S. A. (2011). Pembangunan Program Homestay di Wilayah Utara Semenanjung Malaysia : Profil , Produk dan Prospek. GEOGRAFIA Online Malaysia Journal of Society and Space 7 issue $2,45-54$.

KEMENPAREKRAF. (2014). Salinan Peraturan Menteri Pariwisata Dan Ekonomi Kreatif Republik Indonesia Nomor 9 Tahun 2014. Jakarta: Kementrian Pariwisata dan Ekonomi Kreatif (KEMENPAREKRAF).

Nugroho, D. S. (2018). Community Based Tourism Tantangan Dusun Nglepen dalam Pengembangan Desa Wisata . Jurnal Pariwisata .

Pertiwi, P. R. (2013). Penerapan Hospitality Tourism Di Desa Wisata Penglipuran Ditinjau dari Attractions, Amenities, Ancillaries, and Community Involvemnet . Jurnal Ilmiah Hospitality Management Vol.4 No.1 .

Pristiwasa, I. W. (2017). Analisis Faktor Hospitality Masyarakat Terhadap Wisatawan di Kawasan Wisata Pulau Penyengat Kota Tanjung Pinang Propinsi Kepulauan Riau . Journal Of Accounting and Management Innovation Vol.1 No.1 .

Sutrisno, B. (n.d.). Profil Singkat Desa Pasirmulya . Retrieved September 14, 2018, from Profil BKM Desa Pasirmulya Kecamatan Banjaran Kabupaten Bandung Jawa Barat : http://www.academia.edu/7624621/Profil_BKM_Desa_Pasirmulya_Kecamatan_Banjaran_Kab upaten_Bandung_Jawa_Barat

Sesotyaningtyas, M., \& Manaf, A. (2015). Analysis of Sustainable Tourism Village Development at Kutoharjo Village, Kendal Regency of Central Java. Procedia-Social and Behavioral Sciences , 184, 273-280.

NN., (2017). Tambaksari, Purwodadi, Pasuruan, Jawa Timur . Journal Of Indonesian Tourism and Development Studies Vol.1 No.1 . 